\title{
FAKTOR - FAKTOR YANG MEMPENGARUHI KUNJUNGAN WISATAWAN DI TAMAN NASIONAL GEDE PANGRANGO (TNGP)
}

\author{
The Factors Witch Are Influences To A Tourism Visitor In Gede Pangrango \\ National Park (Gpnp)
}

\author{
Oleh/By: \\ Epi Syahadat
}

\begin{abstract}
Gede Pangrango National Park has a lot of various object and attractive capacity natural recreation (OACNR), such as a bighest biodiversities like flora, fauna, and ecosystems (magnificent view get into It). The total visitors came to Gede Pangrango National Park could be influenced by services factor, infra structure factor, object and attractive capacity natural recreation factor, and security factor, therefor to know the bigest and dominant influences from those factors in collectively to total visitor, this research was conduct. This researh was conducted on June 2005. The sample were taken by accidental sampling method of 142 respondents. Data were collected by field orientation, interview, and duplicated secondary data. Analyzing data were done by multiple regresion analysis method, and data preparation done by using SPSS for windows 12 version programe. The result showed that services, infra stucture, object and attrative capacity natural recreation and security factors in collectively manner has influences to total visitors, but it was not significant in Gede Pangrango National Park. But on the other hand in partial manner from those four factors, security factor has a dominant and significant influence to total visitor in Gede Pangrango National Park.
\end{abstract}

Key words : Gede Pangrango National Park, services, infra stucture, object and attraction capacity natural recreation, security

\begin{abstract}
ABSTRAK
Taman Nasional Gede Pangrango memiliki berbagai obyek dan daya tarik wisata alam (ODTWA), seperti keanekaragaman hayati yang cukup tinggi baik flora, fauna, maupun ekosistemnya termasuk keindahan panorama alamnya. Jumlah kunjungan ke Taman Nasional Gede Pangrango dapat dipengaruhi oleh faktor pelayanan, faktor sarana prasarana, faktor obyek dan daya tarik wisata alam (ODTWA), dan faktor keamanan. Karena itu untuk mengetahui besarnya pengaruh faktor-faktor tersebut secara bersamasama (simultan) terhadap jumlah pengunjung, maka dilakukan penelitian ini. Penelitian ini dilakukan pada bulan Juni 2005 dengan penentuan sampel secara accidental sampling yang dilakukan secara acak sederhana, dengan jumlah responden sebanyak 142 orang. Pengumpulan data dilakukan dengan cara orientasi lapangan, wawancara, maupun duplikasi data sekunder. Analisis data dilakukan dengan menggunakan metode analisis regresi linier berganda, pengolahan data dilakukan menggunakan program "SPSS for windows versi 12". Hasil penelitian menunjukkan bahwa faktor pelayanan, faktor sarana prasarana, faktor obyek dan daya tarik wisata alam, dan faktor keamanan secara bersama-sama (simultan) mempunyai pengaruh terhadap jumlah pengunjung akan tetapi tidak secara nyata (tidak signifikan) di Taman Nasional Gede Pangrango. Akan tetapi secara parsial, dari keempat faktor tersebut faktor keamanan yang mempunyai pengaruh yang signifikan (nyata) dan dominan terhadap jumlah pengunjung di Taman Nasional Gede Pangrango.
\end{abstract}

Kata kunci : Taman Nasional Gede Pangrango, pelayanan, sarana prasarana, obyek dan daya tarik wisata alam, keamanan.

\section{PENDAHULUAN}

Indonesia merupakan salah satu negara kepulauan memiliki kekayaan alam yang melimpah, terutama potensi keanekaragaman hayati yang menempati urutan kedua, setelah Brazil. Sehingga Indonesia dikenal sebagai "Negara Dengan Keanekaragaman Hayati Tertinggi di Dunia (Megabiodiversity)“ (Anonim, 2003).

Namun demikian, melimpahnya sumber daya alam dan tingginya potensi keanekaragaman hayati bukan merupakan jaminan meningkatnya kesejahteraan, bahkan bagi kelangsungan hidup 
dan kehidupan rakyat Indonesia, jika sumber daya alam tersebut tidak dikelola dengan cara yang bijaksana.

Fakta menunjukan bahwa terjadinya penurunan kualitas maupun kuantitas sumber daya alam hayati yang kita miliki sebagai akibat dari adanya kegiatan pengelolaan dan pemanfaatan sumber daya alam yang berlebihan tanpa mengindahkan aspek-aspek kelestariannya. Keadaan demikian diperparah dengan adanya krisis ekonomi yang berkepanjangan hingga timbul krisiskrisis yang lain.

Di era reformasi dimana banyak dibicarakan tentang adanya tuntutan perbaikan, akan tetapi sangat disayangkan arti reformasi tersebut belum sepenuhnya dipahami oleh sebagian besar masyarakat kita. Reformasi telah banyak mengakibatkan kerusakan lingkungan, penjarahan pembakaran, dan penebangan liar. Semua tindakan tersebut tentu mempunyai dampak yang sangat merugikan bagi kelangsungan hidup dan kehidupan manusia.

Dalam menyikapi hal-hal tersebut di atas, pemerintah telah berupaya melindungi dan melestarikan sumber daya alam melalui berbagai kebijakan teknis diantaranya adalah dengan menetapkan sebagian kawasan hutan sebagai kawasan konservasi baik di darat maupun diperairan, dalam bentuk kawasan Hutan Suaka Alam, Kawasan Hutan Pelesterian Alam, dan Taman Buru. Hingga saat ini telah ditetapkan kawasan konservasi seluas 22,5 juta Ha lebih. Bahkan upaya ini masih akan terus dilanjutkan di masa-masa yang akan datang, agar dapat tercapai target kawasan konservasi seluas 30 juta Ha (Sriyono, 2000).

Upaya penetapan kawasan konservasi ini hanya merupakan langkah awal untuk melindungi kekayaan keanekaragaman hayati yang ada didalamnya. Langkah berikutnya adalah bagaimana mengelola kawasan konservasi tersebut agar dapat berfungsi sebagai benteng tempat hidupnya berbagai jenis kekayaan alam, baik flora, fauna maupun ekosistemnya.

Taman Nasional Gede Pangrango (TNGP), adalah salah satu kawasan konservasi di Jawa Barat yang memiliki potensi keanekaragaman hayati yang cukup tinggi baik flora, fauna, maupun ekosistemnya termasuk keindahan panorama alamnya..

Jumlah pengunjung ke TNGP dari tahun ke tahun memang cenderung mengalami kenaikan, rata-rata kunjungan pertahun sebanyak, 55.319 orang (Tabel 1), akan tetapi peningkatan jumlah kunjungan dari tahun ke tahun bukan merupakan suatu hasil kerja yang optimal. Pada dasarnya pengelolaan TNGP mempunyai potensi yang lebih baik dari sekarang. Permasalahannya adalah bagaimana kawasan TNGP dapat dipertahankan keunikannya baik dari potensi flora, fauna, maupun ekosistemnya, bahkan diharapkan dalam menunjang Penghasilan Negara Bukan Pajak (PNBP) untuk lebih besar lagi kontribusinya.

Dalam upaya untuk mempertahankan bahkan meningkatkan jumlah kunjungan wisatawan ke TNGP ada beberapa faktor yang mempengaruhi minat wisatawan untuk berkunjung ke TNGP, seperti : pelayanan, sarana prasarana, obyek dan daya tarik wisata alam (ODTWA), dan keamanan. Oleh karena itu penelitian tentang faktor-faktor tersebut dalam mempengaruhi tingkat kunjungan ini sangatlah perlu dilakukan sebagai upaya mengoptimalkan pengelolaan Taman Nasional Gede Pangrango.

Penelitian ini bertujuan :

1. Untuk mengetahui besarnya pengaruh faktor pelayanan, sarana prasarana, ODTWA, dan keamanan secara bersama-sama (simultan) terhadap jumlah kunjungan di TNGP.

2. Untuk mengetahui faktor mana di antara keempat faktor tersebut di atas yang mempunyai pengaruh paling dominan terhadap jumlah kunjungan wisata.

Dengan diketahuinya faktor-faktor yang mempengaruhi jumlah kunjungan wisatawan di Taman Nasional Gede Pangrango serta faktor-faktor yang paling dominan, maka diharapkan hasil penelitian ini dapat digunakan sebagai bahan pertimbangan dalam pengambilan keputusan dalam upaya meningkatkan jumlah kunjungan wisata di Taman Nasional Gede Pangrango.

\section{METODOLOGI PENELITIAN}

\section{A. Waktu Dan Lokasi Penelitian}

Penelitian ini dilaksanakan di kawasan Taman Nasional Gede Pangrango Kabupaten Cianjur Propinsi Jawa Barat dengan obyek penelitian adalah para pengunjung / wisatawan yang datang ke Taman Nasional Gede Pangrango pada bulan Juni 2005. Mengingat waktu dan dana 
yang terbatas, maka untuk memenuhi kebutuhan data primer sebagai data dasar dalam menganalisis, maka pengumpulan data primer dilakukan pada tanggal 3 Juni 2005 s/d 14 Juni 2005.

\section{B. Kerangka Pemikiran}

Tujuan yang ingin di capai dalam pemasaran pariwisata menurut National Tourism Organization (NTO), dalam Wahab (1997), adalah :

1 Lebih banyak wisatawan yang datang.

2 Lebih lama mereka tinggal.

3 Lebih banyak mereka membelanjakan uang.

Untuk mencapai tujuan tersebut, seorang manajer pemasaran harus menerapkan strategi bauran pemasaran baik melalui produk yang dihasilkan, harga yang ditawarkan, penyaluran (tempat) yang dilakukan dan kegiatan promosi yang dijalankan.

Menurut Kotler (1995), bauran pemasaran adalah kelompok kiat pemasaran yang digunakan untuk mencapai sasaran / pasar yang terdiri dari : produk, harga, promosi, dan tempat. Bauran pemasaran sektor pariwisata itu mengacu kepada faktor penentu yang menyebabkan wisatawan memutuskan untuk membeli produk wisata, yaitu produk dan tempat

Suwantoro (1997) mengemukakan bahwa produk wisata, merupakan gabungan dari berbagai komponen, antara lain :

a. Atraksi suatu daerah tujuan wisata.

b. Fasilitas / amenities yang tersedia.

c. Aksesibilitas ke dan dari daerah tujuan wisata.

Kemudian, menurut Suwantoro (1997) unsur pokok yang harus mendapat perhatian guna menunjang pengembangan pariwisata di daerah tujuan wisata, meliputi :

- Obyek dan Daya Tarik Wisata (ODTW).

- Prasarana Wisata.

- Sarana Wisata.

- Tata Laksana (pelayanan, keamanan, dan kenyamanan).

- Masyarakat / Lingkungan.

Berdasarkan pernyataan-pernyataan tersebut di atas keberhasilan dalam pengelolaan obyek wisata alam dapat di lihat dari jumlah kedatangan wisatawan, jumlah wisatawan yang datang dipengaruhi oleh beberapa faktor, diantaranya adalah :

1. Faktor pelayanan (X1), pernyataan wisatawan tentang sikap dan prilaku dalam memberikan jasa pelayanan, pemanduan, dan informasi kepada wisatawan, dengan indikator (a) keramahan, (b) kecepatan, (c) keakuratan / kesesuaian informasi yang diberikan, dan (d) kualitas pemandu wisata dalam menerangkan obyek tersebut. Di Taman Nasional Gede Pangrango (TNGP) jenis pelayanan yang diberikan, yaitu : Pelayanan proses perijinan dan atau penjualan tiket masuk kawasan, Pelayanan informasi, dan Pelayanan pemanduan.

2. Faktor sarana prasarana (X2), yaitu pernyataan wisatawan tentang fasilitas yang mendukung kelancaran aktivitas wisatawan selama berada di daerah/lokasi obyek wisata, dengan indikator (a) ketersediaan dan (b) kelayakan, .

3. Faktor obyek dan daya tarik wisata alam (ODTWA) (X3), yaitu potensi ODTWA yang berbasis pengembangan pariwisata alam yang bertumpu pada potensi utama sumber daya alam (natural and cultural based tourism). Demikian halnya dengan pengembangan pariwisata alam di Taman Nasional Gede Pangrango yang memiliki potensi ODTWA yang cukup tinggi, antara lain berupa keanekaragaman hayati, atraksi kehidupan satwa liar dan keindahan panorama alam.

4. Faktor keamanan (X4), tingkat gangguan / kerawanan keamanan di suatu obyek wisata alam akan mempengaruhi ketenangan dan kenyamanan wisatawan selama berada di obyek wisata alam tersebut, disamping itu faktor keamanan tersebut juga akan mempengaruhi wisatawan dalam mengambil keputusan layak atau tidak obyek wisata alam tersebut untuk dikunjungi.

Dengan keadaan demikian, maka konstelasi atau hubungan antara pelayanan, sarana prasarana, ODTWA, keamanan terhadap jumlah kunjungan / wisatawan, digambarkan secara bagan, sebagai berikut : 


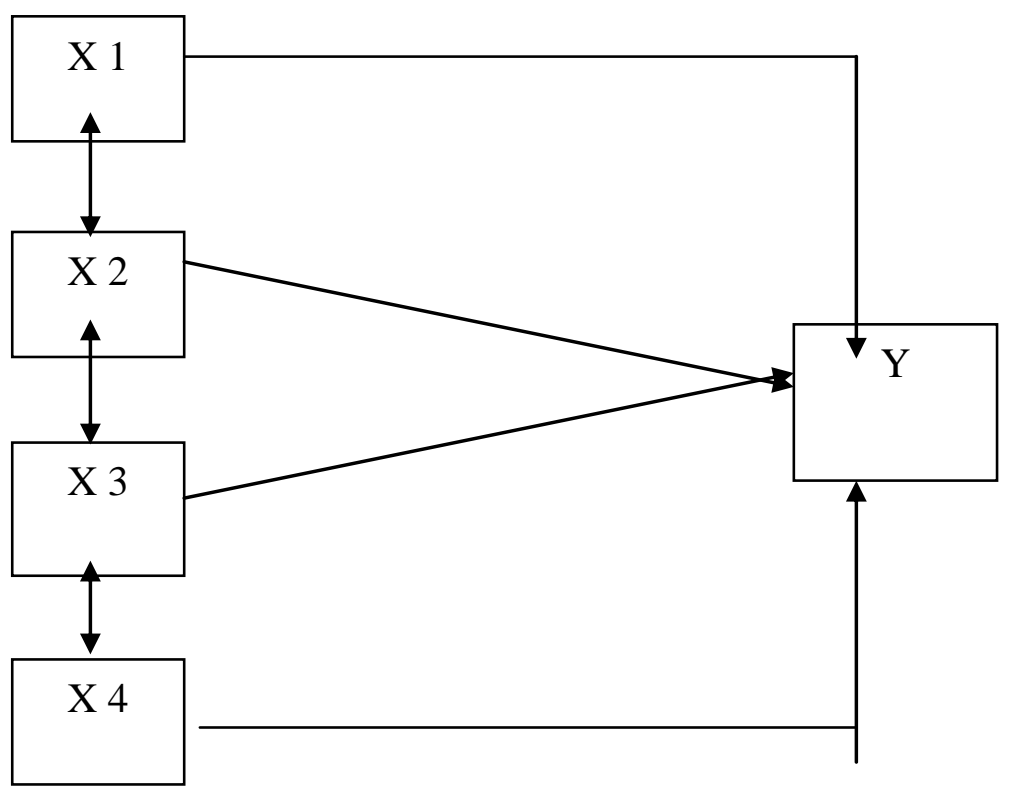

Gambar : Kerangka Berpikir

\section{Pembuatan Model}

Penelitian ini dirancang untuk mengetahui faktor-faktor yang mempengaruhi jumlah kunjungan wisatawan di Taman Nasional Gede Pangrango. Berdasarkan permasalahan yang ada dan kerangka pemikiran yang telah dibuat, maka variabel-variabel yang akan dianalisis dikelompokan menjadi 2 bagian yaitu variabel bebas (independent variable) dan variabel tergantung/terikat (dependent variale), adalah sebagai berikut :

1. Variabel tidak bebas/terikat $(\mathrm{Y})$, yaitu jumlah pengunjung / wisatawan di Taman Nasional Gede Pangrango.

2. $\quad$ Variabel bebas (X), yaitu :

$\mathrm{X} 1$ = Pelayanan

$\mathrm{X} 2=$ Sarana Prasarana

X3 = Obyek dan Daya Tarik Wisata Alam (ODTWA)

$\mathrm{X} 4$ = Keamanan.

Dalam penelitian ini, pengumpulan data dilakukan dengan teknik, sebagai berikut :

a. Penelitian Lapangan, yaitu dengan melakukan penelitian langsung di lokasi penelitian untuk mendapatkan data, informasi, atau keterangan lain yang diperlukan. Adapun instrumen yang digunakan adalah kuesioner. Teknik ini dipilih semata-mata karena : Subyek adalah orang yang mengetahui dirinya sendiri, dan apa yang dinyatakan oleh subyek kepada peneliti adalah benar dan dapat dipercaya, dan inteprestasi subyek tentang pernyataan yang diajukan kepada subyek adalah sama dengan apa yang dimaksud oleh peneliti.

b. Studi Kepustakaan, dilakukan dengan cara membaca dan mengutip baik secara langsung maupun tidak langsung dari literatur-literatur yang berhubungan langsung dengan variabel penelitian.

\section{Teknik Pengambilan Sampel}

Penentuan sampel dilakukan dengan cara Accidental Sampling, yaitu teknik penentuan sampel berdasarkan kebetulan, yaitu siapa saja yang secara kebetulan bertemu dan dipandang orang tersebut cocok dan dapat dijadikan sebagai sumber data (Sugiyono, 1999). Sedangkan yang dijadikan sampel penelitian adalah sebanyak 142 orang (19,48\%). Menurut Arikunto (1987), untuk sekedar ancer-ancer, apabila jumlah populasi kurang dari 100 orang sebaiknya diambil semua, 
sedangkan apabila jumlahnya cukup besar dapat diambil 10\% - 15\% atau 25\% - 35\%. Dengan demikian secara teoritis jumlah sampel sebanyak 19,48\% sudah memenuhi ketentuan.

Kuesioner yang digunakan dalam penelitian ini merujuk pada skala model Likert. Skala berisi sejumlah pernyataan yang menyatakan obyek yang hendak diungkap.

Penskoran atas kuesioner skala model Likert yang digunakan dalam penelitian ini merujuk pada lima alternatif jawaban, yakni : Sangat Baik (5), Baik (4), Cukup Baik (3), Tidak Baik (2), dan Sangat Tidak Baik (1).

\section{E. Pengukuran Variabel Bebas}

Jumlah pengunjung /wisatawan yang datang pada tanggal 3 s/d 14 juni 2005 sebanyak 729 orang, dan 142 orang diantaranya atau 19,48\% dijadikan sampel penelitian (responden) yang dipilih secara acak, kemudian melalui lembar pernyataan (kuisioner) mereka diminta untuk menyampaikan pendapatnya tentang hal-hal yang terkait dengan pelayanan, sarana prasarana, obyek dan daya tarik wisata alam (ODTWA), dan keamanan di Taman Nasional Gede Pangrango. Dari jawaban atau pernyataan responden yang dibuat, kemudian di hitung nilai skornya per responden dan per jenis variabel bebasnya. Untuk keperluan analisis data, dari jumlah nilai skor yang diperoleh berdasarkan jenis variabel bebasnya, nilai tersebut dibuat nilai rata-rata berdasarkan jumlah responden yang di ambil per hari nya (lihat Tabel 3), kemudian data nilai ratarata skoring tersebut diolah melalui komputer dengan menggunakan proram SPSS for windows versi 12.

Model analisis yang digunakan dalam penelitian ini adalah Analisis Regresi Linier Berganda (Multiple Regresion Analisys), yang dilanjutkan dengan menghitung koefisien korelasi, nilai koefisien determinasi, dan pengujian hipotesis dengan $\mathrm{t}$ test dan $\mathrm{F}$ test. Model ini dipilih karena penulis ingin mengetahui seberapa besar pengaruh faktor pelayanan, sarana prasarana, obyek dan daya tarik wisata alam (ODTWA), dan keamanan terhadap jumlah pengunjung / wistawan di Taman Nasional Gede Pangrango baik secara simultan maupun parsial.

Untuk keperluan analisis data digunakan alat bantu komputer dengan program SPSS For Window Versi 12. hasil perhitungan dapat diperoleh dari hasil "print oue" program tersebut. Hal ini dilakukan atas pertimbangan sebagai berikut:

a. Hasil pengolahan data lebih baik, tepat dan akurat.

b. $\quad$ Mempercepat proses analisis data sehingga kendala waktu dapat diatasi

Persamaan umum Regresi Linear Berganda, adalah sebagai berikut :

$\mathrm{Y}=\mathrm{a}+\mathrm{b}_{1} \mathrm{X}_{1}+\mathrm{b}_{2} \mathrm{X}_{2}$

Keterangan :

$\mathrm{Y}=$ Subyek dalam variabel dependen yang diprediksikan.

$\mathrm{a} \quad=$ Harga y bila $\mathrm{X}=0$ (harga konstan)

$\mathrm{b}=$ Angka arah atau koefisien regresi, yang menunjukan angka peningkatan ataupun penurunan variabel dependen yang didasarkan pada variabel independen.

Untuk menghitung koefisien korelasi digunakan rumus Product Moment Pearson :

$$
r_{X Y}=\frac{n \sum X Y-\sum X \sum Y}{\sqrt{n} \sum X^{2}-\sum X j \sqrt{n} \sum Y^{2}-\sum Y^{2}}
$$

Keterangan :

$\mathrm{r}_{\mathrm{xy}}=$ Koefisien Korelasi

$\mathrm{n} \quad=$ Jumlah Subyek

$\mathrm{X}=$ Skor setiap item

$\mathrm{Y} \quad=$ Skor Total

$\left(\sum X\right)^{2}=$ Kuadrat jumlah skor item

$\sum \mathrm{X}^{2}=$ Jumlah kuadrat skor item

$\sum \mathrm{Y}^{2}=$ Jumlah kuadrat skor total

$\left(\sum \mathrm{Y}\right)^{2}=$ Kuadrat jumlah skor total

Perhitungan nilai koefisien determinasi, untuk mengukur seberapa besar variabel-variabel independen dapat menjelaskan variabel dependen, digunakan koefisien multikorelasi atau koefisien determinasi $\left(\mathrm{R}^{2}\right)$. Koefisien ini menunjukan proporsi variabilitas total pada variabel 
dependen yang dijelaskan oleh model regresi. Nilai $\mathrm{R}^{2}$ berada pada interval $0 \leq \mathrm{R}^{2} \leq 1$. Logikanya adalah, semakin baik estimasi model dalam menggambarkan data, maka semakin dekat nilai $\mathrm{R}$ ke nilai 1 (satu). Nilai $\mathrm{R}^{2}$ dapat diperoleh dengan rumus :

$\mathrm{R}^{2}=(\mathrm{r})^{2}$ X $100 \%$

Keterangan :

$\mathrm{R}^{2}=$ Koefisien determinasi

$\mathrm{r}=$ Koefisien korelasi

Uji hipotesis dengan t-test digunakan untuk mengetahui apakah variabel independen signifikan atau tidak terhadap variabel dependen secara individual untuk setiap variabel. Rumus yang digunakan untuk mengetahui nilai t-hitung, adalah sebagai berikut :

$$
t-\text { hitung }=\frac{r \sqrt{n-2}}{\sqrt{1-r^{2}}}
$$

Setelah didapatkan nilai t-Hitung melalui rumus diatas, maka untuk menginterpretasikan hasilnya berlaku ketetapan sebagai berikut:

$>\quad$ Jika t-hitung $>\mathrm{t}$-tabel $\rightarrow$ Ho ditolak (ada hubungan yang signifikan).

$>\quad$ Jika t-hitung $<\mathrm{t}$-tabel $\rightarrow$ diterima (tidak ada hubungan yang signifikan).

Untuk mengetahui t-tabel digunakan ketentuan $\mathrm{n}-2$ pada level of significance $(\alpha)$ sebesar $5 \%$ (tingkat kesalahan $5 \%$ atau 0,05$)$ atau taraf keyakinan $95 \%$ atau 0,95 . Jadi apabila tingkat kesalahan suatu variabel lebih dari $5 \%$ berarti variabel tersebut tidak signifikan.

Uji hipotesis dengan $\mathrm{f}$-test digunakan untuk menguji hubungan dua variabel atau lebih secara bersama-sama dengan variabel dependen. Rumusnya adalah sebagai berikut :

$$
F h=\frac{R^{2} / k}{\left(-R^{2}\right) N \ll-1}
$$

Keterangan :

$\mathrm{r}^{2}=$ Koefisien determinasi

$\mathrm{K}=$ Jumlah variabel independen

$\mathrm{N}$ = Jumlah sampel

Nilai f-hitung $>$ f-tabel, berarti Ho ditolak, Ha diterima

\section{HASIL PEMBAHASAN}

\section{A. Gambaran Umum Taman Nasional Gede Pangrango}

Keberadaan Taman Nasional Gede Pangrango mempunyai arti yang penting, karena Taman Nasional ini merupakan kawasan yang pertama ditetapkan sebagai cikal bakal cagar alam di Indonesia, dan merupakan salah satu dari lima Taman Nasional yang tertua di Indonesia. Pembentukan Taman Nasional Gede Pangrango berdasarkan Pengumuman Menteri Pertanian tanggal 6 Maret 1980, dengan luas kawasan seluas 15.196 Ha yang terdiri dari :

1 Kawasan Zona Inti seluas 7.446,90 Ha.

2 Kawasan Zona Rimba seluas 6.800,70 Ha.

3 Kawasan Zona Pemanfaatan seluas 948,40 Ha..

Pada tahun 2003 luas kawanan Taman Nasional Gede Pangrango bertambah menjadi $21.975 \mathrm{Ha}$, sesuai dengan Surat Keputusan Menteri Kehutanan Nomor 174/Kpts-II/2003, tanggal 10 juni 2003, dan berdasarkan Surat Keputusan tersebut di atas, kawasan ini dijadikan sebagai kawasan pelestarian alam.

Secara umum tujuan pengelolaan Taman Nasional Gede Pangrango (Anonim, 2004), adalah sebagai berikut :

a. Terjamin dan terpelihara fungsi hidrologi, keseimbangan ekologi, kesuburan tanah, dan kestabilan iklim mikro.

b. Terjamin dan terpeliharanya keberadaan potensi dan nilai-nilai dari keanekaragaman tumbuhan, satwa, komunitas, dan ekosistem penyusunan kawasan TNGP.

c. Meningkatnya upaya penelitian sumber daya alam TNGP.

d. Meningkatnya upaya pendidikan konservasi alam dilingkungan TNGP.

e. Meningkatkan peran TNGP dalam pengembangan pariwisata dan rekreasi. 
f. Meningkatkan peran TNGP dalam menunjang budidaya.

g. Meningkatkan kesejahteraan masyarakat sekitar kawasan TNGP.

Pengelolaan TNGP yang baik dan profesional, diharapkan mampu mendorong peningkattan jumlah kunjungan wisatawan ke TNGP.

1 Jenis-jenis Obyek dan Daya Tarik Wisata Alam (ODTWA).

Kawasan Taman Nasional Gede Pangrango memiliki keaneka- ragaman hayati yang cukup tinggi, seperti : a) Jenis Flora, jenis tumbuhan berbunga (1.500 spesies), paku-pakuan (400 spesies), lumut (120 spesies), tumbuhan obat-obatan (300 species), dan tumbuhan yang berstatus dilindungi (10 species). b) Potensi Fauna, dalam kawasan ini terdapat berbagai jenis fauna, seperti insekta (300 spesies), reptilia (75 spesies), amphibia (20 species), dan mamalia (110 spesies) c) Potensi Hidrologi, kawasan ini merupakan daerah tangkapan air untuk masyarakat sekitar kawasan yang terletak di tiga Kabupaten yaitu Bogor, Cianjur, dan Sukabumi. d) Potensi keindahan alam, seperti air terjun, telaga, air panas, kawah, dan lain sebagainya mempunyai potensi untuk dikembangkan. Dengan ketersediaan potensi alam yang begitu besar, maka sudah sejak lama hutan Gunung Gede Pangrango menjadi tempat penelitian flora dan fauna yang dikembangkan untuk dapat dimanfaatkan bagi berbagai kepentingan seperti pendidikan, rekreasi alam, dan penunjang budi daya.

\section{Sarana Prasarana}

Taman Nasional Gede Pangrango dapat dicapai melalui enam (6) daerah, yaitu : a) Pintu masuk Cibodas (termasuk wilayah Kabupaten Cianjur), merupakan pintu utama dan terletak di dekat Kantor Balai Taman Nasional Gede Pangrango. b) Pintu masuk Gunung Putri (masuk ke wilayah Cianjur), berdekatan dengan Cibodas $\pm 10 \mathrm{Km}$, dapat di capai melalui Cipanas Pacet. c) Pintu masuk Salabintana dan Situgunung (masuk wilayah Kabupaten Sukabumi). d) Pintu masuk Bodogol termasuk wilayah Kabupaten Bogor, yang dapat di tempuh dari jalur Bogor-Sukabumi di desa Tenjo Ayu. e) Pintu Masuk Cisarua termasuk wilayah Kabupaten Bogor, melalui jalur Bogor-Puncak di desa Citeko.

\section{Pelayanan}

Faktor pelayanan merupakan pernyataan wisatawan tentang sikap dan prilaku dalam memberikan jasa pelayanan, pemanduan, dan informasi kepada wisatawan, dengan indikator (a) keramahan, (b) kecepatan, (c) keakuratan / kesesuaian informasi yang diberikan, dan (d) kualitas pemandu wisata dalam menerangkan obyek tersebut. Di Taman Nasional Gede Pangrango (TNGP) jenis pelayanan yang diberikan, yaitu : Pelayanan proses perijinan dan atau penjualan tiket masuk kawasan, Pelayanan informasi, dan Pelayanan pemanduan.

\section{Keamanan}

Faktor keamanan merupakan tingkat gangguan / kerawanan keamanan terhadap pengunjung di suatu obyek wisata alam, karena faktor keamanan akan mempengaruhi ketenangan dan kenyamanan wisatawan selama berada di obyek wisata alam tersebut, disamping itu faktor keamanan tersebut juga akan mempengaruhi wisatawan dalam mengambil keputusan layak atau tidak obyek wisata alam tersebut untuk dikunjungi. Di Taman Nasional Gede Pangrango untuk menjaga keamanan dan kenyamanan pengunjung, seperti mendirikan pos penjagaan serta petugas jaga yang siap melayani 24 jam sehari, memberikan informasi tentang hal-hal yang terkait dengan kondisi dan keamanan kawasan, memberikan rambu-rambu dan papan informasi di tempat yang rawan gangguan keamanan, melengkapi sarana prasarana alat komunikasi dan P3K dan lain sebagainya.

\section{Jumlah Pengunjung / Wisatawan}

Pada Tabel 1 di bawah dapat dilihat perkembangan jumlah pengunjung / wisatawan di Taman Nasional Gede Pangrango (TNGP) dari tahun 1992 s/d tahun 2004, jumlah pengunjung ke Taman Nasional Gede Pangrango (TNGP) setiap tahunnya berfluktuasi. Terjadinya fluktuasi jumlah pengunjung / wisatawan tersebut tentu dipengaruhi oleh berbagai faktor, adapun faktor yang di duga berpengaruh terhadap jumlah pengunjung / wisatawan yaitu faktor pelayanan, sarana prasarana, obyek dan daya tarik wisata alam (ODTWA), dan keamanan. 
Tabel 1 Jumlah Pengunjung Ke Taman Nasional Gede Pangrango Tahun 1992 s/d Tahun 2004.

Table 1 Total Visitors To Gede Pangrango National Park From Year 1992 Until Year 2004

\begin{tabular}{|c|c|c|c|c|c|c|c|}
\hline No & $\begin{array}{c}\text { Tahun } \\
\text { (Year) }\end{array}$ & \multicolumn{2}{|c|}{$\begin{array}{c}\text { Wisatawan Nusantara } \\
\text { (Domestic Visitors) }\end{array}$} & \multicolumn{2}{|c|}{$\begin{array}{c}\text { Wisatawan Mancanegara } \\
\text { (Foreign Visitors) }\end{array}$} & \multicolumn{2}{|c|}{$\begin{array}{c}\text { Jumlah wisatawan } \\
\text { (Total Visitors) }\end{array}$} \\
\hline & & Jumlah & $\%$ & Jumlah & $\%$ & Jumlah & $\%$ \\
\hline 1 & 1992 & 54.635 & 7,77 & 1.200 & 7,39 & 55.835 & 7,76 \\
\hline 2 & 1993 & 51.057 & 7,26 & 1.541 & 9,49 & 52.598 & 7,31 \\
\hline 3 & 1994 & 31.568 & 4,49 & 930 & 5,73 & 32.498 & 4,52 \\
\hline 4 & 1995 & 40.011 & 5,69 & 1.027 & 6,33 & 41.038 & 5,71 \\
\hline 5 & 1996 & 43.334 & 6,16 & 1.260 & 7,76 & 44.594 & 6,20 \\
\hline 6 & 1997 & 49.334 & 7,02 & 1.366 & 8,41 & 50.700 & 7,05 \\
\hline 7 & 1998 & 54.731 & 7,79 & 1.886 & 11,62 & 56.617 & 7,87 \\
\hline 8 & 1999 & 56.101 & 7,98 & 597 & 3,68 & 56.698 & 7,88 \\
\hline 9 & 2000 & 58.854 & 8,37 & 1.002 & 6,17 & 59.856 & 8,32 \\
\hline 10 & 2001 & 50.838 & 7,23 & 1.336 & 8,23 & 52.174 & 7,25 \\
\hline 11 & 2002 & 67.217 & 9,56 & 967 & 5,96 & 68.184 & 9,48 \\
\hline 12 & 2003 & 68.510 & 9,75 & 1.974 & 12,16 & 70.484 & 9,80 \\
\hline 13 & 2004 & 76.725 & 10,93 & 1.147 & 7,07 & 77.872 & 10,83 \\
\hline & Jumlah & 702.915 & 100 & 16.233 & 100 & 719.148 & 100 \\
\hline & Rata-rata & $54.070,38$ & & $1.248,69$ & & $55.319,08$ & \\
\hline
\end{tabular}

Sumber : Taman Nasional Gede Pangrango, 2005.

Source : Gede Pangrango National Park, 2005.

Untuk memenuhi kebutuhan analisis data maka obyek atau sasaran dalam penelitian ini, adalah responden atau wisatawan yang datang ke Taman Nasional Gede Pangrango (TNGP) pada bulan Juni 2005, akan tetapi karena keterbatasan dana dan waktu penelitian, maka responden yang diambil sebagai sampel penelitian adalah wisatawan yang berkunjung pada tanggal 3 juni $2005 \mathrm{~s} / \mathrm{d}$ tanggal 14 Juni 2005, dengan intensitas sampling 10\% - 15\% (Arikunto, 1987) per hari, sebagaimana tertera pada Tabel 2. di bawah ini :

Tabel 2. Jumlah Pengunjung / Wisatawan Dan Sampel Penelitian Pada Tanggal 3 s/d 14 Juni 2005.

Table 2 Total Visitors And Research Sampling From Dates 3 Until 14June 2005

\begin{tabular}{|c|c|c|c|}
\hline No & $\begin{array}{c}\text { Tanggal } \\
\text { (Dates) }\end{array}$ & $\begin{array}{c}\text { Jumlah Wisatawan } \\
\text { (Total Visitors) } \\
\text { (Orang / Person) }\end{array}$ & $\begin{array}{c}\text { Jumlah Sampel } \\
\text { (Total Sample) } \\
\text { (Orang / Person) }\end{array}$ \\
\hline 1 & 3 Juni 2005 & 30 & 6 \\
\hline 2 & 4 Juni 2005 & 46 & 10 \\
\hline 3 & 5 Juni 2005 & 115 & 21 \\
\hline 4 & 6 Juni 2005 & 75 & 12 \\
\hline 5 & 7 Juni 2005 & 60 & 12 \\
\hline 6 & 8 Juni 2005 & 70 & 8 \\
\hline 7 & 9 Juni 2005 & 42 & 7 \\
\hline 8 & 10 Juni 2005 & 7 & 12 \\
\hline
\end{tabular}




\begin{tabular}{|c|c|c|c|}
\hline 9 & 11 Juni 2005 & 32 & 6 \\
\hline 10 & 12 Juni 2005 & 120 & 22 \\
\hline 11 & 13 Juni 2005 & 80 & 16 \\
\hline 12 & 14 Juni 2005 & 52 & 10 \\
\hline & Jumlah & 729 & 142 \\
\hline
\end{tabular}

Sumber : Data Diolah.

Source : Data Calculated

Pada Tabel 2. terlihat jumlah pengunjung / wisatawan yang datang pada tanggal $3 \mathrm{~s} / \mathrm{d} 14$ juni 2005 sebanyak 729 orang. 142 orang $(19,48 \%)$ diantaranya dijadikan sampel penelitian (responden) yang dipilih secara acak.

Adapun jumlah pengunjung yang dijadikan sampel dari tanggal 3 Juni 2005 s/d 14 Juni 2005 dan rata-rata nilai skor per variabel bebas (X1, X2, X3, dan X4) dapat dilihat pada Tabel 3 di bawah, adalah sebagai berikut :

Tabel 3. Rekapitulasi Jumlah Responden (Y) dan Nilai Skor Rata-rata Variabel Bebas (X1, X2, X3, dan X4).

Table 3 Recapitulation Total Respondent (Y) And Scoring Rate Value Independent Variables (X1,X2, X3, And X4)

\begin{tabular}{|c|c|c|c|c|c|}
\hline $\begin{array}{l}\text { Hari } \\
\mathrm{Ke} \\
(\text { Days })\end{array}$ & $\begin{array}{c}\text { Pengunjung / } \\
\text { wisatawan } \\
\text { (Visitors) }\end{array}$ & $\begin{array}{c}\text { Pelayanan } \\
\text { (Services) } \\
\text { (X1) }\end{array}$ & $\begin{array}{c}\text { Sarana } \\
\text { Prasarana } \\
\text { (Infra Structure) } \\
\text { (X2) }\end{array}$ & $\begin{array}{c}\text { ODTWA } \\
(O A C N R) \\
(\mathrm{X} 3)\end{array}$ & $\begin{array}{c}\text { Keamanan } \\
\text { (Security) } \\
\text { (X4) }\end{array}$ \\
\hline 1 & 6 & 14 & 6 & 12 & 6 \\
\hline 2 & 10 & 13 & 6 & 12 & 6 \\
\hline 3 & 21 & 14 & 6 & 12 & 6 \\
\hline 4 & 12 & 13 & 6 & 12 & 7 \\
\hline 5 & 12 & 15 & 7 & 12 & 7 \\
\hline 6 & 12 & 14 & 7 & 12 & 6 \\
\hline 7 & 8 & 14 & 7 & 12 & 7 \\
\hline 8 & 7 & 13 & 6 & 13 & 6 \\
\hline 9 & 6 & 13 & 7 & 13 & 7 \\
\hline 10 & 22 & 13 & 6 & 13 & 6 \\
\hline 11 & 16 & 14 & 7 & 12 & 7 \\
\hline 12 & 10 & 13 & 6 & 12 & 6 \\
\hline
\end{tabular}

\section{B. Pengaruh Variabel Bebas (X) Terhadap Variabel Tak Bebas (Y) Secara Bersama- sama (Simultan)}

Untuk melihat pengaruh faktor pelayanan, sarana prasarana, obyek dan daya tarik wisata alam (ODTWA), dan keamanan terhadap jumlah pengunjung / wisatawan di Taman Nasional Gede Pangrango (TNGP), maka data primer yang diperoleh dari responden tersebut di olah melalui komputer dengan menggunakan program SPSS For Windows Versi 12. Adapun hasil pengolahan dan perhitungan dapat dilihat pada Tabel 4 di bawah, adalah sebagai berikut : 
Tabel 4 Rekapitulasi Hasil Analisis Regresi Linier Berganda

Table 4 Recapitulation Analysis Results Multiple Regresion Linear

\begin{tabular}{|l|c|c|c|c|c|}
\hline \multicolumn{1}{|c|}{ Variabel Bebas } & $\begin{array}{c}\text { Koefisien } \\
\text { Regresi }\end{array}$ & T Test & $\begin{array}{c}\text { T Tabel } \\
\alpha=0,05\end{array}$ & R Parsial & $\mathrm{R}^{2}$ \\
\hline Pelayanan & $-1,780$ & $-0,492$ & 1,812 & $-0,125$ & 0,16 \\
\hline Sarana Prasarana & $-1,695$ & $-0,404$ & 1,812 & $-0,170$ & 0,29 \\
\hline ODTWA & $-5,424$ & $-1,176$ & 1,812 & $-0,19$ & 0,00 \\
\hline Keamanan & 4,305 & 2,106 & 1,812 & 0,483 & 0,233 \\
\hline Konstanta & 84,475 & & F Ratio & 1.203 & \\
\hline $\mathrm{R}$ (MultipleR) & 0,638 & & F Tabel & 4,12 & \\
\hline $\mathrm{R}^{2}$ & 0,407 & & $\mathrm{Y}$ & Jumlah Pengunjung & \\
\hline $\mathrm{n}$ & 12 & & & & \\
\hline
\end{tabular}

Sumber : Disalin dari lampiran

Source : Translation From Appendix

Dari hasil perhitungan analisis regresi (pada Tabel 4), dapat disusun persamaam regresinya, adalah sebagai berikut :

$$
Y=84,475-1,780 X 1-1,695 X 2-5,424 X 3+4,305 X 4
$$

Dalam persamaan ini tampak nilai konstanta sebesar 84,475, secara matematis nilai konstanta ini menyatakan bahwa pada saat pelayanan, sarana parasarana, ODTWA, dan keamanan bernilai nol (0), maka jumlah pengunjung memiliki nilai 84,475. Dari persamaan tersebut di atas dapat dilihat nilai negatif untuk koefisien regresi variabel pelayanan (X1), sarana prasarana (X2), dan ODTWA (X3), ini menggambarkan bahwa hubungan antara variabel pelayanan (X1), sarana prasarana (X2), dan ODTWA (X3) dengan variabel tidak bebas (jumlah pengunjung / Y) tidak searah, yang berarti setiap kenaikan satu satuan variabel pelayanan (X1), sarana prasarana (X2), dan ODTWA (X3), akan menyebabkan penurunan jumlah pengunjung / wisatawan, sebesar (berturut-turut) 1,780,1,695, dan 5,424. Sebaliknya nilai positif yang terdapat pada koefisien regresi variabel keamanan (X4) senilai 4,305, ini menggambarkan bahwa arah hubungan antara variabel keamanan (X4) dengan variabel terikat (Jumlah pengunjung / Y), adalah searah, ini berarti setiap kenaikan satu satuan variabel keamanan (X4), akan menyebabkan kenaikan nilai jumlah pengunjung $(\mathrm{Y})$ sebesar 4,305.

Nilai koefisiensi korelasi $(\mathrm{R})=0,638$, besaran nilai koefisien korelasi ini secara kualitatif tergolong $K \boldsymbol{u a t}$, selanjutnya diketahui juga bahwa nilai koefisien korelasi positif $(0,638)$, hal ini menunjukkan atau mengindikasikan bahwa orientasi hubungan yang searah, ini berarti apabila pelayanan, sarana prasarana, ODTWA, dan keamanan semakin baik, maka jumlah pengunjung akan meningkat.

Nilai koefisien determinasi yang diperoleh, adalah sebesar 0,407 atau $40,70 \%$, hal ini mencerminkan bahwa variabel bebas (pelayanan, sarana prasarana, ODTWA, dan keamanan) mampu menjelaskan variasi perubahan pada variabel terikat (jumlah pengunjung) hanya sebesar $40,70 \%$, adapun sisanya yaitu, sebesar $59,30 \%$ dipengaruhi oleh variabel-variabel lain yang tidak dilibatkan dalam penelitian ini.

Uji hipotesa secara bersamaan atau simultan (uji F), dengan membandingkan nilai $\mathrm{F}$ hitung sebesar 1,203, yang lebih kecil $(<)$ dari nilai $F$ tabel pada taraf nyata $\alpha=0,01$, (F tab 4,12), ini berarti HO diterima, Ha ditolak atau dengan perkataan lain bahwa secara bersama-sama atau simultan variabel bebas (pelayanan, sarana prasarana, ODTWA, dan keamanan) berpengaruh terhadap jumlah pengunjung, akan tetapi tidak secara nyata (tidak signifikan).

\section{Pengaruh Masing-masing Variabel Bebas (X) Terhadap Variabel Tidak Bebas (Y)}

Uji parsial dilakukan untuk mengetahui atau menguji apakah masing-masing variabel bebas (X) mempunyai pengaruh yang bermakna (signifikan) atau tidak terhadap variabel tidak bebasnya (Y), dengan cara membandingkan nilai t hitung dengan nilai t tabel pada taraf nyata $\quad \alpha=$ 0,05 . Untuk mengetahui ada atau tidaknya hubungan variabel bebas $(X)$ secara parsial terhadap 
variabel tidak bebas $(\mathrm{Y})$, dapat dilihat dari besarnya nilai koefisien korelasi (r), sedangkan untuk mengetahui seberapa besar pengaruh variabel bebas secara parsial terhadap variabel tidak bebasnya dapat diketahui dari masing-masing koefisien determinasi parsialnya $\left(\mathrm{r}^{2}\right)$. Adapun hasil analisis untuk masing-masing variabel tersebut, adalah sebagai berikut :

1. Pengaruh Variabel Pelayanan (X1) terhadap Jumlah Pengunjung $(\mathrm{Y})$.

Dari hasil perhitungan statistik (Tabel, 4), menunjukan t hitung - 0,492, sedangkan $t$ tabel sebesar 1,812, ini berarti t hitung lebih kecil $(<)$ dari t tabel, dengan demikian dapat disimpulkan bahwa variabel pelayanan (X1) tidak mempunyai pengaruh yang signifikan terhadap jumlah pengunjung $(\mathrm{Y})$ di Taman Nasional Gede Pangrango.

Pengaruh yang tidak signifikan juga dapat dilihat dari nilai koefisien korelasi parsialnya (r), yaitu sebesar - 0,125, nilai koefisien korelasi ini secara kualitatif tergolong Sangat Rendah, selanjutnya diketahui juga bahwa nilai koefisien korelasi tersebut bernilai negatif $(-0,125)$, hal ini menunjukkan bahwa orientasi hubungan yang tidak searah antara pelayanan (X1), dengan Jumlah pengunjung $(\mathrm{Y})$, ini berarti walaupun pelayanan ditingkatkan lebih baik akan tetapi jumlah pengunjung belum tentu meningkat.

Koefisien determinasi yang diperoleh adalah sebesar 0,16 atau dalam persentase $16 \%$, hal ini mencerminkan bahwa variabel bebas (pelayanan) hanya mampu menjelaskan variasi perubahan variabel tidak bebas / terikat (jumlah pengunjung), sebesar $16 \%$, sedangkan sisanya yaitu $84 \%$ dipengaruhi oleh variabel sarana prasarana, ODTWA, keamanan dan variabel lainnya yang tidak dilibatkan dalam penelitian ini.

2. Pengaruh Variabel Sarana Prasarana (X2) terhadap Jumlah Pengunjung (Y).

Dari hasil perhitungan statistik (Tabel, 4), menunjukan thitung - 0,404, sedangkan $\mathrm{t}$ tabel sebesar 1,812, ini berarti thitung lebih kecil $(<)$ dari t tabel, dengan demikian dapat disimpulkan bahwa variabel sarana prasarana (X2) tidak mempunyai pengaruh yang signifikan terhadap jumlah pengunjung (Y) di Taman Nasional Gede Pangrango.

Pengaruh yang tidak signifikan juga dapa dilihat dari nilai koefisien korelasi parsialnya (r), yaitu sebesar - 0,170, nilai koefisien korelasi ini secara kualitatif tergolong Sangat Rendah, selanjutnya diketahui juga bahwa nilai koefisien korelasi tersebut bernilai negatif $(-0,170)$, hal ini menunjukkan bahwa orientasi hubungan yang tidak searah antara sarana prasarana (X2), dengan Jumlah pengunjung $(\mathrm{Y})$, ini berarti walaupun sarana prasarana diperbaiki atau diperbaharui akan tetapi jumlah pengunjung belum tentu meningkat.

Koefisien determinasi yang diperoleh adalah sebesar 0,29 atau dalam persentase $29 \%$, hal ini mencerminkan bahwa variabel bebas (sarana prasarana) hanya mampu menjelaskan variasi perubahan variabel tidak bebas / terikat (jumlah pengunjung) sebesar $29 \%$, dan sisanya yaitu $71 \%$ dipengaruhi oleh variabel pelayanan, ODTWA, keamanan dan variabel lainnya yang tidak dilibatkan dalam penelitian ini.

3. Pengaruh Variabel Obyek dan Daya Tarik Wisata Alam (ODTWA / X3) terhadap Jumlah Pengunjung $(\mathrm{Y})$.

Dari hasil perhitungan statistik (tabel, 4), menunjukan t hitung - 1,176, sedangkan $\mathrm{t}$ tabel sebesar 1,812, ini berarti t hitung lebih kecil $(<)$ dari t tabel, dengan demikian dapat disimpulkan bahwa variabel ODTWA (X3) tidak mempunyai pengaruh yang signifikan terhadap jumlah pengunjung $(\mathrm{Y})$ di Taman Nasional Gede Pangrango.

Pengaruh yang tidak signifikan juga dapa dilihat dari nilai koefisien korelasi parsialnya (r), yaitu sebesar - 0,19, nilai koefisien korelasi ini secara kualitatif tergolong Sangat Rendab, selanjutnya diketahui juga bahwa nilai koefisien korelasi tersebut bernilai negatif $(-0,19)$, hal ini menunjukkan bahwa orientasi hubungan yang tidak searah antara ODTWA (X3), dengan jumlah pengunjung $(\mathrm{Y})$, ini berarti bahwa obyek dan daya tarik wisata alam (ODTWA) bukan merupakan hal yang utama atau istimewa bagi pengunjung, walupun obyek dan daya tarik wisata alam (ODTWA) tersebut dibuat lebih bervariasi atraksi atau kegiatan yang ditampilkan, seperti dengan diadakan berbagai macam atraksi satwa, upacara tradional dan lain sebagainya akan tetapi tidak menjamin jumlah pengunjung akan meningkat.

Koefisien determinasi yang diperoleh adalah sebesar 0,000 atau dalam persentase $0 \%$, hal ini mencerminkan bahwa variabel bebas obyek dan daya tarik wisata alam (ODTWA) tidak 
mampu menjelaskan variasi perubahan variabel tidak bebas / terikat (jumlah pengunjung), perubahan variabel tidak bebas / terikat lebih banyak dipengaruhi oleh variabel pelayanan, sarana prasarana, keamanan dan variabel lainnya yang tidak dilibatkan dalam penelitian ini.

4. Pengaruh Variabel Keamanan (X3) terhadap Jumlah Pengunjung (Y).

Dari hasil perhitungan statistik (tabel, 4), menunjukan t hitung 2,106, sedangkan $t$ tabel sebesar 1,812, ini berarti thitung lebih besar $(>)$ dari $\mathrm{t}$ tabel, dengan demikian dapat disimpulkan bahwa variabel keamanan (X4) mempunyai pengaruh yang signifikan terhadap jumlah pengunjung $(\mathrm{Y})$ di Taman Nasional Gede Pangrango.

Nilai koefisien korelasi parsialnya (r), yaitu sebesar 0,483 , nilai koefisien korelasi ini secara kualitatif tergolong Sedang, selanjutnya diketahui juga bahwa nilai koefisien korelasi tersebut bernilai positif $(0,483)$, hal ini menunjukkan bahwa orientasi hubungan yang searah antara keamanan (X4), dengan Jumlah pengunjung $(\mathrm{Y})$, ini berarti semakin baik tingkat keamanan, maka jumlah pengunjung akan semakin meningkat.

Koefisien determinasi yang diperoleh adalah sebesar 0,233 atau dalam persentase 23,3\%, hal ini mencerminkan bahwa variabel bebas (keamanan) hanya mampu menjelaskan variasi perubahan variabel tidak bebas / terikat (jumlah pengunjung) sebesar 23,3\%, dan sisanya yaitu $76,7 \%$ dipengaruhi oleh variabel pelayanan, sarana prasarana, ODTWA, dan variabel lainnya yang tidak dilibatkan dalam penelitian ini.

\section{Pembahasan}

Dari hasil analisis yang dilakukan menunjukkan bahwa variabel bebas yang terdiri dari pelayanan, sarana parsarana, obyek dan daya tarik wisata alam (ODTWA), dan keamanan secara bersama-sama (simultan) mempunyai pengaruh terhadap jumlah pengunjung di Taman Nasional Gede Pangrango, akan tetapi tidak secara nyata (tidak signifikan), hal ini dapat dilihat dari perolehan F hitung $(1,203)$, lebih kecil $(<)$ dari $\mathrm{F}$ tabel $(4,12)$ dengan taraf nyata $\alpha=0,01$.

Nilai koefisien korelasi $(\mathrm{R})=0,638$, besaran nilai ini secara kualitatif tergolong Kuat, selanjutnya diketahui bahwa nilai koefisien korelasi positif $(0,638)$ menunjukkan atau mengindikasikan bahwa orientasi hubungan yang searah, berarti apabila pelayanan, sarana prasarana, ODTWA dan keamanan semakin baik maka jumlah pengunjung akan meningkat.

Nilai koefisien determinasi yang diperoleh adalah sebesar 0,407 atau dalam persentase $40,70 \%$, hal ini mencerminkan bahwa variabel bebas (pelayanan, sarana prasarana, ODTWA, dan keamanan) secara bersama-sama (simultan) hanya mampu menjelaskan variasi perubahan variabel tidak bebas (jumlah pengunjung) sebesar 40,70\%, sedangkan sisanya 59,30\% dipengaruhi oleh variabel lain yang tidak dilibatkan dalam penelitian ini.

Dari persamaan regresi secara bersama-sama atau secara simultan menunjukkan bahwa hubungan yang terjadi antara seluruh variabel bebas $(\mathrm{X})$ dengan variabel tidak bebas $(\mathrm{Y})$ tidak menggambarkan hubungan yang searah, hal ini dapat dilihat dari koefisien regresi variabel pelayanan (X1), sarana prasarana (X2), dan ODTWA (X3) bertanda negatif, sedangkan koefisien regresi variabel keamanan (X4) bertanda positif, pengertian dari hal tersebut adalah jika variabel pelayanan (X1), sarana prasarana (X2), dan ODTWA (X3) ditingkatkan sedangkan variabel keamanan (X4) konstan, maka akan berdampak terhadap penurunan jumlah pengunjung di Taman Nasional Gede Pangrango, sebaliknya apabila variabel keamanan (X4) ditingkatkan sedangkan variabel pelayanan (X1), sarana prasarana (X2), dan ODTWA (X3) konstan maka akan berdampak terhadap peningkatan jumlah pengunjung / wisatawan di Taman Nasioal Gede Pangrango.

Secara teoritis memang benar bahwa apabila jaminan keamanan ditingkatkan, maka secara psikologis akan berpengaruh terhadap tingkat kepuasan dan kenyamanan, tentunya hal ini mempunyai dampak (kecenderungan) yang positif bagi peningkatan jumlah pengunjung / wisatawan yang datang ke Taman Nasional Gede Pangrango. Namun tidak demikian halnya untuk variabel pelayanan (X1), sarana prasarana (X2), dan ODTWA (X3) justru kecenderungan negatif, jika kualitas ketiga variabel tersebut ditingkatkan. Sepintas lalu hal ini bertolak belakang dengan logika berpikir kita karena wisatawan seharusnya merasa puas, apabila pelayanan yang diberikan lebih baik, dengan penyediaan sarana prasarana dan obyek dan daya tarik wisata alam (ODTWA) ditingkatkan. 
Kalau kita lihat/tinjau lebih jauh mengapa variabel pelayanan, sarana prasarana, dan ODTWA berpengaruh negatif terhadap jumlah pengunjung / wisatawan di Taman Nasional Gede Pangrango, memang agak sulit untuk dijelaskan, akan tetapi dari hasil analisa kuantitatif bahwa koefisien korelasi parsial dari ketiga variabel tersebut sangat kecil $(\mathrm{X} 1=-0,125, \mathrm{X} 2=$ 0,170, dan X3 = - 0,19), sehingga hubungan yang terjadi antara ketiga variabel pelayanan, sarana prasarana, dan ODTWA dengan variabel jumlah pengunjung / wisatawan sangat rendah atau lemah, lebih jauh didukung dengan hasil uji t, dimana t hitung $(\mathrm{X} 1=-0,492, \mathrm{X} 2=-0,404$, dan X3 = - 1,176) jauh lebih kecil dibandingkan dengan $t$ tabel $(1,812)$ pada taraf nyata $\alpha=0,05$. dengan demikian dapat disimpulkan bahwa ketiga variabel tersebut yaitu pelayanan, sarana prasarana, dan ODTWA tidak mempunyai pengaruh yang signifikan terhadap perubahan jumlah pengunjung / wisatawan di Taman Nasional Gede Pangrango.

Secara kualitatif hal tesebut dapat disebabkan oleh faktor wisatawan itu sendiri, terutama yang menyangkut masalah pengetahuan dan wawasan mereka tentang hal-hal yang terkait dengan pelayanan yang diberikan, sarana prasarana yang mereka butuhkan, faktor ODTWA dan jenis kunjungan yang mereka lakukan. Hasil pengamatan dilapangan diketahui bahwa sebagian besar wisatawan $(97,74 \%$ ) yang datang adalah wisatawan domistik yang lama kunjunganya kurang dari 12 jam, sehingga selama berkunjung tidak memanfaatkan atau membutuhkan sarana prasarana yang tersedia. Disamping itu karena obyek dan daya tarik wisata alam (ODTWA) di Taman Nasional Gede Pangrango merupakan obyek wisata minat khusus, dimana intensitas pemanfaatan sarana prasarana relatif rendah, akibatnya jawaban yang mereka berikan sangat beragam baik menyangkut masalah kualitas maupun kuantitas pelayanan, sarana prasarana ataupun menyangkut masalah keterpikatan obyek dan daya tarik wisata alam (ODTWA).

\section{KESIMPULAN DAN SARAN}

\section{Kesimpulan}

a. Berdasarkan hasil analisis yang diperoleh bahwa faktor pelayanan, sarana prasarana, obyek dan daya tarik wisata alam (ODTWA), dan keamanan secara bersama-sama (simultan) mempunyai pengaruh terhadap jumlah pengunjung / wisatawan akan tetapi tidak signifikan (tidak secara nyata) di Taman Nasional Gede Pangrango pada taraf nyata $\alpha=$ 0,01. Akan tetapi secara parsial dari keempat faktor tersebut hanya satu yang mempunyai pengaruh yang signifikan (nyata), yaitu faktor keamanan, sedangkan 3 (tiga) faktor lainnya yaitu pelayanan, sarana prasarana, dan obyek dan daya tarik wisata alam (ODTWA), mempunyai pengaruh terhadap jumlah pengunjung / wisatawan akan tetapi tidak signifikan (tidak secara nyata) di Taman Nasional Gede pangrango.

b. Dari hasil analisis diketahui bahwa faktor variabel keamanan yang mempunyai pengaruh paling dominan diantara faktor variabel bebas lainnya, dengan nilai koefisien regresinya sebesar (+ 4,305), hal ini didukung oleh nilai koefisien korelasi parsialnya sebesar ( $\mathrm{r}=$ 0,483), secara kualitatif nilai koefisien korelasi ini tergolong Sedang, selanjutnya diketahui juga nilai koefisien korelasi tersebut bernilai positif, hal ini menunjukan bahwa orientasihubungan yang searah antara keamanan (X4) dengan jumlah pengunjung (Y) ini berarti semakin baik tingkat keamanan, maka jumlah pengunjung akan semakin meningkat. Nilai t hitung variabel keamanan sebesar $(2,106)$, lebih besar $(>)$ dari nilai t tabel sebesar $(1,812)$ pada taraf nyata $\alpha=0,05$, dengan demikian dapat disimpulkan bahwa variabel keamanan (X4) mempunyai pengaruh yang signifikan (nyata) terhadap jumlah pengunjung di Taman Nasional Gede Pangrango.

\section{Saran}

a. Mengingat faktor keamanan mempunyai pengaruh yang paling dominan terhadap jumlah pengunjung / wisatawan di Taman Nasional Gede Pangrango, maka dalam rangka meningkatkan jumlah pengunjung perlu diciptakan atau diupayakan situasi dan kondisi yang kondusif. Upaya tersebut dapat dilaksanakan dengan cara menekan / mengurangi peluang timbulnya gangguan atau meningkatkan kesiagaan petugas keamanan, adapun upaya yang dilakukan, adalah sebagai beriklut : 
Memberikan informasi secara benar kepada wisatawan tentang hal-hal yang terkait dengan kondisi dan keamanan kawasan yang akan dikunjungi.

Pemasangan rambu-rambu dan papan informasi ditempat-tempat yang rawan gangguan keamanan.

> Melengkapi sarana dan prasarana pengamanan alat komunikasi dan P3K.

$>$ Menempatkan petugas ditempat-tempat yang rawan gangguan keamanan.

> Memberikan jaminan keamanan secara pasti kepada setiap pengunjung / wisatawan melalui pelayanan asuransi.

> Setiap wisatawan yang datang wajib dipandu / didampingi petugas, lebih lagi wisatawan mancanegara.

b. Walaupun faktor pelayanan tidak mempunyai pengaruh yang signifikan (nyata) terhadap jumlah pengunjung / wisatawan di Taman Nasional Gede Pangrango, akan tetapi hal tersebut tidak bisa diabaikan atau dibiarkan begitu saja, karena faktor pelayanan dalam skup yang lebih luas (pengembangan industri pariwisata alam) mempunyai peranan yang cukup penting di dalam mempengaruhi tingkat kepuasan pengunjung / wisatawan, oleh karena itu faktor pelayanan tersebut harus tetap menjadi perhatian semua pihak yang terkait, terlebih lagi apabila yang menjadi segmen pasar dalam pengembangan obyek dan daya tarik wisata alam (ODTWA) Taman Nasional Gede Pangrango adalah wisatawan mancanegara, dengan perkataan lain kualitas pelayanan harus tetap ditingkatkan agar berdampak positif terhadap perubahan jumlah pengunjung atau wisatawan.

c. Obyek dan daya tarik wisata alam (ODTWA) yang dipasarkan saat ini masih bertumpu pada potensi alam, oleh karena itu dalam rangka menarik dan meningkatkan jumlah pengunjung / wisatawan hendaknya ODTWA tersebut dikembangkan dan di kemas sedemikian rupa sehingga produk wisata yang dipasarkan atau dijual tidak hanya memiliki keunggulan komparatif, tetapi juga memiliki keunggulan kompetitif.

\section{DAFTAR PUSTAKA}

Arikunto Sukarsini., 1987. Prosedur Penelitian, Suatu Pendekatan Praktek. Bina Aksara. Jakarta.

Anonim., 2003. Rencana Pengembangan Pariwisata Alam Nasional Di Kawasan Hutan. Direktorat Wisata Alam Dan Pemanfaatan Jasa Lingkungan. Direktorat Jenderal Perlindungan Hutan Dan Konservasi Alam. Bogopr.

Anonim., 2004 Review Rencana Pengelolaan Taman Nasional Gede Pangrango Tahun 19952020. Balai Taman Nasional Gunung Gede Pangrango. Bogor.

Kotler Philip, 1995. Manajemen Pemasaran. Buku Satu. Edisi Kedelapan. Terjemahan Salemba Empat. PT. Prenhelindo. Jakarta.

Suwartono gamal, 1997. Dasar-dasar Pariwisata. Edisi Pertama. Cetakan Pertama. Penerbit andi. Yogyakarta.

Sugiyono., 1999. Metode Penelitian Bisnis. Cetakan Ketujuh. Alfabeta. Bandung

Sriyono., 2000. Pengembangan Pariwisata Alam Di Kawasan Konservasi. Direktorat Pengembangan Wisata Alam Hutan Dan Kebun. Bogor.

Wahab Saleh, 1997. Pemasaran Pariwisata. Cetakan Ketiga. Alih Bahasa : Frans Gromang. PT. Pradnya Paramita. Jakarta. 